\title{
Novel and Emerging Routes for Titanium Powder Production - An Overview Ian Mellor ${ }^{a *}$ and Greg Doughty ${ }^{b}$
}

\author{
Metalysis Limited, Unit 2 - Farfield Park, Manvers Way, Wath-upon-Dearne, Rotherham, S63 5DB. \\ United Kingdom.

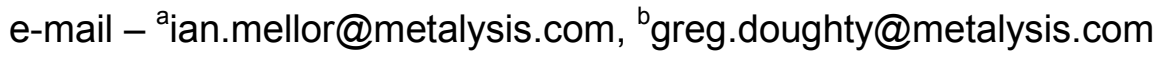

\begin{abstract}
Keywords: Metalysis, FFC ${ }^{\circledR}$ Cambridge Process, titanium powder, titanium alloys, additive manufacturing, powder metallurgy.
\end{abstract}

\begin{abstract}
As the adoption of components fabricated via titanium powder metallurgy (PM) techniques becomes more prevalent, and projected to increase at a substantial rate over the next decade, especially in the field of additive manufacturing (AM), there is a necessity to increase titanium powder production capacity from the current annual level of ca. 6000 tonnes per annum. At present a well-documented barrier restricting this widespread implementation, is the inherently high cost of the feedstock, an issue which to date has been neglected to some degree, at the expense of developing the individual powder metallurgy routes. The scope of this overview therefore is to provide an insight of both established and novel methods of titanium powder production, as potential opportunities to satisfy this growing demand. Particular emphasis will focus on Metalysis, a company founded to commercialize an innovative electrochemical approach for the synthesis of metals and alloys from their respective oxides, where the ability to generate titanium eloquently demonstrates the extent of its capabilities.

The patented Metalysis technology, exploiting the FFC $^{\circledR}$ Cambridge process, lends itself to producing alloys and intermetallics, where Ti-6Al-4V provides a prime example of this. Furthermore, as electrolysis occurs solely in the solid state, issues pertaining to segregation due to dissimilar densities and melting points are avoided. It is possible to tailor both the average particle diameter and size distribution of the product's targeted powder metallurgy (PM) applications, based upon appropriate selection of the feed. The attraction of this strategy is that the steps associated with conventional metal powder synthesis are circumvented, resulting in a significant cost reduction. Moreover it has recently been revealed that titanium can be produced directly from naturally occurring ore (beach sand) and synthetic rutile, with the ensuing product presenting itself as an inexpensive and abundant feedstock for additive manufacturing (AM). This represents a paradigm shift in the availability of consumables for the 3D printing market.
\end{abstract}

\section{Introduction}

Although titanium exhibits a range of desirable properties such as a high strength to weight ratio, excellent corrosion resistance, and bio-compatibility, a significant barrier preventing its wide spread use, is the cost associated with manufacturing a finished part. With regards to this, the breakdown of the individual constituents required to mill process titanium alloy plate via conventional means is depicted in (Figure 1) [1]. As the plot indicates, approximately half of the expense equates to fabrication, therefore as a consequence significant effort has been dedicated to reduce this. Powder metallurgy (PM) presents a prospective solution to this, offering a range of benefits, including the ability to generate near net shapes (NNS), thus reducing the buy to fly ratio, an indicator used by the aerospace industry to compare the amount of material purchased, versus that contained in a final component. Under certain circumstances this can be as high as 40:1 [2]. Other advantages are that less scrap is generated, incorporating a reduced energy consumption associated with less machining, resulting in an enhanced environmental impact. 


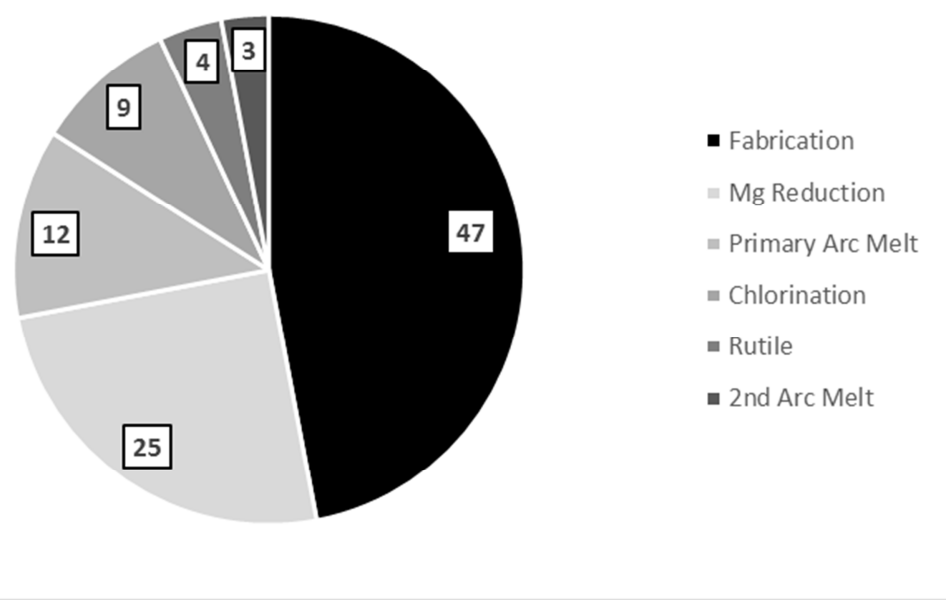

Figure 1 Relative Cost Factors for Conventional Milling of Titanium Alloy Plate [1].

A number of accepted powder metallurgy techniques currently exist, including but not limited to Metal Injection Moulding (MIM), Hot Isostatic Pressing (HIP), Cold Isostatic Pressing (CIP) combined with subsequent heat treatment, and Additive Manufacturing (AM). These are augmented by emerging methods such as Spark Plasma Sintering (SPS) or Field Assisted Sintering Technology (FAST), Gas Dynamic Cold Spray (GDCS) and several development concepts such as the direct production of sheet [3] and continuous rotary extrusion (CRE) of wire [4], i.e. the Conform process.

Naturally the accessibility of a cost effective, consistent product within a stable supply chain, is a pre-requisite to stimulate the growth of titanium powder metallurgy. Obtaining reliable historic information relating to the magnitude of the global market is somewhat difficult, due to the overall opaqueness of the industry. Circa 2008 this was estimated to be in the region of 6,000tpa [5], where the split in terms of production route is portrayed in (Figure 2). By 2013 hydride dehydride (HDH) shipments had increased steadily to 1,750tpa [2], and it is projected that by 2020 total output will reach 19,000tpa, being over three times that of 2008 levels, dominated by spherical powders for additive manufacturing at 10,000tpa [5]. A more conservative but still bullish forecast has recently been announced by SmarTech Publishing [6], predicting an increase in the latter to roughly 730 tpa over a similar timeframe.

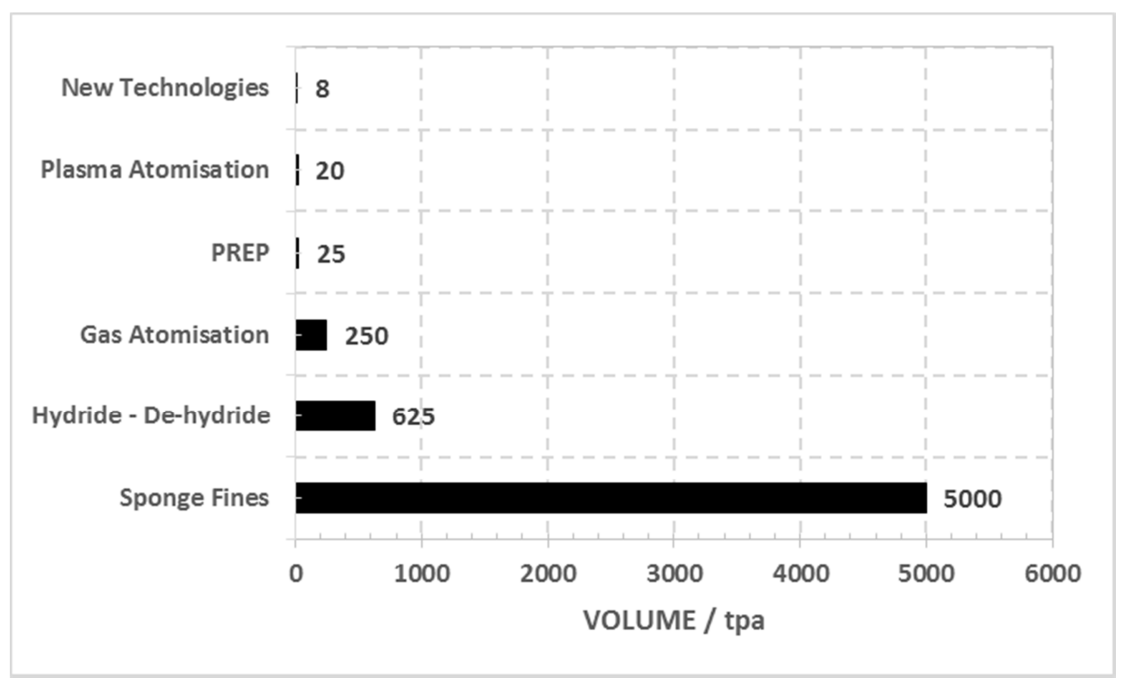

Figure 2 Estimated Global Titanium Powder Production Levels in 2008 by Type [5].

Although a discrepancy exists between the two projections, the outlook is promising. Therefore it is evident that capacity needs to rise over the next five years to satisfy this growing demand, especially in the provision of consumables for 3D printing. Consequently this opportunity provides 
the necessary impetus for the emergence of new entrants, both in terms of novel or existing routes, and established suppliers to expand capacity in conjunction with improving efficiencies. This last point is particularly salient as titanium powders are considered expensive in relative terms, where currently approximately half the cost of an additively manufactured part corresponds to the feed [7], presenting an obstacle to wide spread deployment.

The aim of this paper is to provide an overview of a range of novel techniques presently under consideration, with specific reference to Metalysis, a start-up company spun out of the University of Cambridge, to commercialize the $\mathrm{FFC}^{\circledR}$ Cambridge process. Although powder production is dominated by a combination of traditionally synthesized Kroll or Hunter sponge fines (Figure 2) used predominantly in the blended elemental approach [2], these will not be covered as part of this review, as they are both recognized mature technologies. The different avenues to powder can be classified into three main categories being (i) chemical, (ii) electrochemical, and (iii) melting via either gas or plasma atomization/spheroidization. Each of these will now be addressed in greater detail below.

\section{Chemical Routes to Titanium Powder}

The most prevalent method for producing titanium powder via chemical means is hydride - dehydride (HDH). The feedstock, either Ti-6Al-4V or commercially pure wrought scrap, otherwise unalloyed Kroll/Hunter sponge, is heated in a hydrogen atmosphere at temperatures reaching $400^{\circ} \mathrm{C}$ [8], to cause embrittlement. The material is subsequently crushed and washed, prior to being subjected to a second treatment at $700-800^{\circ} \mathrm{C}$ [9] to release the hydrogen. The resulting product is angular in nature, lending itself to cold pressing, where the irregular morphology promotes interlocking between individual grains to limit voidage. Also due to their porous nature, the particles exhibit improved compressibility during compaction. Typical size distributions before classification are in the range $10-250 \mu \mathrm{m}$, as demonstrated by Yolton [8]. However a drawback associated with this procedure is the pick-up of oxygen during processing, being more pronounced for smaller diameter particles [10]. The main advocates of this technology are Reading Alloys (USA), Toho Titanium Co. Ltd. \& Sumitomo (Japan), TIPRO, Bongen Titanium Co. Ltd., Zunyi Titanium Industry Co. Ltd., Shaanxi North Steel Company, Western Metals Company, Xi'an Titanium \& Affinity International (China), and Se-Jong Materials Ltd. \& Kiswell (South Korea). However it should be noted that this list is not necessarily extensive.

In a variation on this theme a number of the manufacturers circumvent the desorption stage, removing a processing step which can potentially introduce oxygen, to yield hydrogenated titanium. This can be used directly in powder metallurgy, most commonly for blended elemental based processes [2]. It is reported the retained hydrogen aids densification [11], whilst refining and generating an ultrafine grain (UFG) microstructure, leading to improved mechanical properties [11]. Furthermore it has been proposed hydrogen acts as a getter, removing remnant chlorine and oxygen, leading to superior fatigue properties [2].

The nascent chemical based techniques to produce powder are summarized in (Table 1) overleaf. They are metallothermic in nature (a thermic chemical reaction), reducing either a titanium containing halide or oxide precursor. A considerable number of these are devoted to transforming Kroll/Hunter into a continuous process, i.e. Armstrong [2, 9], CSIRO [2, 9] and CSIR [12], whereas ADMA [2, 9] remains batch Kroll, combined with hydride - de-hydride (HDH). Another popular theme is to convert an oxide or a natural/modified titanium bearing mineral, examples being the Direct Reduction of Titanium Slag (DRTS) [13], Pre-Form Reduction Process (PRP) [14] and TiPRO [15]. A common feature associated with all of these alternatives is that the morphology of the ensuing powder is either sponge like or angular in nature, and the primary product is commercially pure titanium, although some do report the ability to generate Ti-6Al-4V, most notably Armstrong [2, 9]. 
Table 1 A Summary of Chemical (Metallothermic) Routes to Produce Titanium Powders.

\begin{tabular}{|c|c|c|c|c|c|c|}
\hline PROCESS & COUNTRY & FEED & REDUCTANT & PRODUCT & FORM & COMMENT \\
\hline ADMA & USA & $\mathrm{TiCl}_{4}$ & $\operatorname{Mg}\left(\& \mathrm{H}_{2}\right)$ & $\mathrm{TiH}_{2}$ & $\begin{array}{l}\text { Angular } \\
\text { powder }\end{array}$ & $\begin{array}{c}\text { Kroll process with } \\
\text { hydrogen injected } \\
\text { during latter } \\
\text { stages }\end{array}$ \\
\hline $\begin{array}{l}\text { Armstrong } \\
\text { (Cristal) }\end{array}$ & USA & $\mathrm{TiCl}_{4}$ & $\mathrm{Na}$ & $\begin{array}{l}\text { Unalloyed } \\
\text { Ti-6Al-4V }\end{array}$ & $\begin{array}{c}\text { Sponge like } \\
\text { powder }\end{array}$ & $\begin{array}{l}\text { Variant on Hunter } \\
\text { process injecting } \\
\text { liquid sodium }\end{array}$ \\
\hline CSIR & $\begin{array}{l}\text { South } \\
\text { Africa }\end{array}$ & $\mathrm{TiCl}_{4}$ & $\mathrm{Mg}$ & $\begin{array}{l}\text { Unalloyed } \\
\text { Alloys } \\
\text { Possible }\end{array}$ & $\begin{array}{c}\text { Sponge like } \\
\text { powder }\end{array}$ & $\begin{array}{l}\text { Continuous Kroll } \\
\text { in a molten salt of } \\
\text { the by-product of } \\
\text { the reaction }\end{array}$ \\
\hline $\begin{array}{l}\text { DRTS } \\
\text { (Utah) }\end{array}$ & USA & $\begin{array}{c}\mathrm{TiO}_{2} \text { slag } \\
\left(80 \% \mathrm{TiO}_{2}\right)\end{array}$ & $\mathrm{MgH}_{2}$ & $\begin{array}{l}\text { Unalloyed } \\
\mathrm{TiH}_{2}\end{array}$ & $\begin{array}{l}\text { Angular } \\
\text { powder }\end{array}$ & $\begin{array}{l}\text { Acid leach to } \\
\text { remove metallic } \\
\text { impurities post } \\
\text { reduction }\end{array}$ \\
\hline $\begin{array}{l}\text { Peruke } \\
\text { (Anglo) }\end{array}$ & $\begin{array}{l}\text { South } \\
\text { Africa }\end{array}$ & $\mathrm{TiF}_{3}$ & $\mathrm{Al}$ & Unalloyed & $\begin{array}{l}\text { Sponge like } \\
\text { powder }\end{array}$ & $\begin{array}{c}\text { Fluorotitanate } \\
\text { precipitated from } \\
\text { FeOTiO }_{2} \text { to form } \\
\mathrm{TiF}_{3}\end{array}$ \\
\hline $\begin{array}{c}\text { PRP } \\
\text { (Okabe) }\end{array}$ & Japan & $\begin{array}{c}\mathrm{TiO}_{2} \\
\text { Rutile }\end{array}$ & $\mathrm{Ca}$ & Unalloyed & $\begin{array}{l}\text { Angular } \\
\text { powder }\end{array}$ & $\begin{array}{l}\text { Performed in a } \\
\text { flux of calcium } \\
\text { chloride }\end{array}$ \\
\hline $\begin{array}{c}\text { TiPRO } \\
\text { (Titanox) }\end{array}$ & $\begin{array}{c}\text { New } \\
\text { Zealand }\end{array}$ & $\mathrm{TiO}_{2}$ & $\mathrm{CaH}_{2}$ & $\begin{array}{l}\text { Unalloyed } \\
\text { Alloys } \\
\text { Possible }\end{array}$ & $\begin{array}{l}\text { Angular } \\
\text { powder }\end{array}$ & $\begin{array}{l}\text { Recently claimed } \\
\text { to produce } \\
\text { titanium aluminide } \\
\text { (Ti-Al) }\end{array}$ \\
\hline $\begin{array}{c}\mathrm{TiRO}^{\mathrm{TM}} \\
(\mathrm{CSIRO})\end{array}$ & Australia & $\mathrm{TiCl}_{4}$ & $\mathrm{Mg}$ & $\begin{array}{c}\text { Unalloyed } \\
\text { Alloys } \\
\text { Possible }\end{array}$ & $\begin{array}{c}\text { Sponge like } \\
\text { powder }\end{array}$ & $\begin{array}{c}\text { Continuous Kroll } \\
\text { process in a } \\
\text { fluidized bed }\end{array}$ \\
\hline
\end{tabular}

\section{Electrochemical Routes to Titanium Powder}

The four principal modes under investigation to manufacture titanium powder via electrochemical means, are given in (Table 2) below.

Table 2 A Summary of Electrochemical Routes to Produce Titanium Powders.

\begin{tabular}{|c||c|c|c|c|c|c|}
\hline PROCESS & COUNTRY & FEED & REDUCTANT & PRODUCT & FORM & COMMENT \\
\hline \hline $\begin{array}{c}\text { FFC } \\
\text { (Metalysis) }\end{array}$ & UK & $\begin{array}{c}\mathrm{TiO}_{2} \\
\text { Rutile }\end{array}$ & Electron & $\begin{array}{c}\text { Unalloyed } \\
\text { Range of alloys }\end{array}$ & $\begin{array}{c}\text { Angular or } \\
\text { spherical } \\
\text { powder }\end{array}$ & $\begin{array}{c}\text { See subsequent } \\
\text { section }\end{array}$ \\
\hline MER & USA & $\begin{array}{c}\mathrm{TiO}_{2} \\
\mathrm{Rutile}\end{array}$ & Electron & $\begin{array}{c}\text { Unalloyed } \\
\text { Alloys possible }\end{array}$ & $\begin{array}{c}\text { Sponge like } \\
\text { powder }\end{array}$ & $\begin{array}{c}\mathrm{Ti}_{2} \mathrm{OC} \text { acts as } \\
\text { anode in electro- } \\
\text { refining process }\end{array}$ \\
\hline $\begin{array}{c}\text { Electro- } \\
\text { refining }\end{array}$ & Various & $\mathrm{TiCl}_{4}$ & Electron & Unalloyed & $\begin{array}{c}\text { Dendritic } \\
\text { like powder }\end{array}$ & $\begin{array}{c}\mathrm{TiCl}_{4} \text { is soluble in } \\
\text { electrolyte and is } \\
\text { deposited at } \\
\text { cathode }\end{array}$ \\
\hline $\begin{array}{c}\text { OS (Ono \& } \\
\text { Suzuki) }\end{array}$ & Japan & $\mathrm{TiO}_{2}$ & $\begin{array}{c}\text { Electron \& } \\
\text { calcium }\end{array}$ & Unalloyed & $\begin{array}{c}\text { Angular } \\
\text { powder }\end{array}$ & $\begin{array}{c}\text { Combines } \\
\text { electrochemical } \\
\text { and calciothermic } \\
\text { reduction }\end{array}$ \\
\hline
\end{tabular}

As evident and anticipated from (Table 2) above, each of the technologies featured utilizes the electron, representing the most economically available reductant [16]. The Metalysis approach, based upon adaptation of FFC ${ }^{\circ}[17]$, originally invented at the University of Cambridge, will form the basis of subsequent sections, therefore will not be discussed in further detail here. The OS (Ono 
\& Suzuki) philosophy symbolizes a variation on $\mathrm{FFC}^{\circledR}$, however instead of relying upon direct electro-deoxidation of an oxide, electrolysis is based upon the initial dissociation of $\mathrm{CaO}$ dissolved in the $\mathrm{CaCl}_{2}$ solvent [18]. The formed calcium is then responsible for performing metallothermic reduction. The patented Polar ${ }^{\circledR}$ process of BHP Billiton follows a broadly similar tact, the rights to which were transferred to Metalysis in 2007.

In the oxy-carbide technique the titanium bearing oxide is reacted in an inert atmosphere, or under vacuum, at temperatures in the region of $1400^{\circ} \mathrm{C}$ to form $\mathrm{Ti}_{2} \mathrm{CO}$ [19]. This is subsequently pressed and sintered, typically at $1700^{\circ} \mathrm{C}$ [19], to form the anode of an electrochemical cell. The powdered product is then deposited on the cathode, generally a stainless steel, via electro-refining. Recent proponents of this are MER Corporation [20], however other institutions and establishments such as Chinuka [15], the Norwegian University of Science and Technology (NTNU) [19], Carnegie Mellon University [21] and the University of Science and Technology Beijing (USTB) [22], have or are currently investigating this route.

\section{Routes to Produce Spherical Titanium Powder}

Presently the area of titanium production attracting the greatest attention, is in the generation of spherical powders, with special focus on additive manufacturing. A number of techniques are under consideration by various parties, being reviewed in (Table 3 ).

Table 3 A Summary of Routes to Produce Spherical Titanium Powders.

\begin{tabular}{|c||l|c|l|}
\hline ACRONYM & TECHNIQUE & FEEDSTOCK & POWDER MANUFACTURERS \\
\hline \hline $\begin{array}{c}\text { TGA or } \\
\text { VIGA }\end{array}$ & $\begin{array}{l}\text { Titanium Gas Atomization or } \\
\text { Vacuum Induction Gas Atomization }\end{array}$ & $\begin{array}{c}\text { Rod/bar/ } \\
\text { billet/chips }\end{array}$ & ATI (USA), Praxair (USA) \\
\hline EIGA & Electrode Induction Gas Atomization & Bar & $\begin{array}{l}\text { TLS Teknik (Germany), Sumitomo } \\
\text { (Japan), Puris (USA), Bongen Titanium } \\
\text { Co. Ltd. (China), FalconTech (China) }\end{array}$ \\
\hline $\begin{array}{c}\text { PREP } \\
\text { REP) }\end{array}$ & $\begin{array}{l}\text { Plasma Rotating Electrode Process } \\
\text { (Rotating Electrode Process or } \\
\text { Centrifugal Atomization) }\end{array}$ & Bar & $\begin{array}{l}\text { TIMET/PCC (USA), Shaanxi North Steel } \\
\text { Company (China), Xi'an Titanium } \\
\text { (China), Affinity International (China) }\end{array}$ \\
\hline PAP & Plasma Atomization Process & Wire & AP\&C (Canada), PyroGenesis (Canada) \\
\hline IPS & Induction Plasma Spheroidization & Powder & Tekna Plasma Systems Inc. (Canada) \\
\hline
\end{tabular}

Gas atomization falls into two main categories, differing with regards to how the feedstock is presented to the chamber. TGA/VIGA involves melting in a vacuum induction water cooled copper crucible, where the molten metal is tapped and consequently atomized, by impinging with a stream of high pressure inert gas - nominally argon. An advantage linked to this system is that the titanium input can assume a range of alternative forms. Furthermore it is claimed alloys can be created directly, by combination and homogenization of the individual constituents during the melt stage, similar to conventional ingot metallurgy. The process was originally pioneered by Crucible Materials Corporation [8], but was later acquired by ATI Powder Metals [7]. A number of companies also supply equipment into this field, namely Phoenix Scientific Instruments (PSI) located in the UK, ALD Vacuum Technologies (Germany) and Arcast Inc. \& Retech Systems LLC, both USA based.

EIGA is differentiated from TGA/VIGA due to the fact that a pre-fabricated titanium rod (electrode), is independently lowered through an induction coil, negating the requirement for a crucible. This is considered important, as it is reported the construction materials of the tundish and/or exit nozzle can be a source of impurities, leading to inclusions in the final product [8]. ALD Vacuum Technologies are again the primary vendors of hardware in this sector.

In a similar manner to EIGA, PREP also employs a bar, which is rotated at high velocity in a helium plasma. This causes the tip to melt and expel the titanium in the form of a spherical particle, which solidifies in a stream of helium gas. This approach was initially developed by Starmet Powders LLC (formerly Nuclear Metals Inc.), who were purchased by Advanced Specialty Metals in 2002 [23], and in turn was obtained by TIMET/PCC (Precision Castparts Corporation). In 
an analogue of this, REP or centrifugal atomization, the desired temperature is achieved using a tungsten arc, rather than a plasma.

With regards to PAP a wire is spooled through a plasma, atomizing the titanium in an inert atmosphere. It was promoted by AP\&C (Advanced Powders \& Coatings), a subsidiary of Raymor Industries Inc. [24], based upon a torch system formerly invented by PyroGenesis, who are still active in this field. The company was sold to Arcam AB, the additive manufacturing machine producer, in late 2013. Finally IPS is a method conceived and operated by Tekna Plasma Systems Inc., to convert irregular shaped titanium powder into a spherical morphology, by directing the particles through an induction plasma.

\section{The Metalysis Process for Producing Titanium Powder}

The elegance of $\mathrm{FFC}^{\circledR}$ lies in its simplicity. The metal oxide (or mixture in the case of an alloy) acts as the cathode in an electrochemical cell, where on application of a nominal voltage between this and the counter electrode, ionization occurs, releasing the liberated oxygen ion $\left(\mathrm{O}^{2-}\right)$ into the electrolyte. Migration to the anode ensues, where it subsequently combines with the electron passed via the external circuit and is evolved as either $\mathrm{CO}$ and $\mathrm{CO}_{2}$ in the case of graphite (carbon), or $\mathrm{O}_{2}$ when using an inert (non-consuming) anode. The net result is that the converted metal product is revealed at the cathode, where it is consequently harvested. Electrolysis is performed in the temperature range $800-1000^{\circ} \mathrm{C}$ in a molten halide salt, generally calcium chloride. Benefits of this are its high ionic $\left(\mathrm{O}^{2-}\right)$ but poor electronic conductivity, attractive cost, and low toxicity, where one of its alternative applications is to deice roads in winter.

Furthermore, as reduction is conducted solely in the solid state, it is possible to generate alloys in a single stage, which are either currently impossible, or challenging to synthesize via conventional means [25]. Titanium - tungsten [26] offers a prime example of this, as boiling of the former $\left(3285^{\circ} \mathrm{C}\right)$ occurs below the onset of melting for the latter $\left(3422^{\circ} \mathrm{C}\right)$. Moreover, numerous treatment steps would be necessary to produce this using more traditional methods, to overcome segregation resulting from mismatched densities (4.51 vs. $\left.19.25 \mathrm{~g} / \mathrm{cm}^{3}\right)$, and achieve full homogenization. The ability to accomplish this provides additional evidence of the vast potential and wide-ranging applicability of the $\mathrm{FFC}^{\circledR}$ process.

In terms of feedstock selection $\mathrm{FFC}^{\circledR}$ has traditionally consumed high purity $\mathrm{TiO}_{2}$ [17], and although it commands typically double the price of $\mathrm{TiCl}_{4}$, as employed in the Kroll process, this is offset by the fact that only $1.66 \mathrm{~kg}$ of the former is required per kilogram of titanium produced, compared to $4 \mathrm{~kg}$ regarding the latter. In a more recent development, it has been demonstrated that it is possible to synthesize powder directly from naturally occurring ore (beach sand) [27], and synthetic rutile [28]. This is considered to be the holy grail in terms of titanium production [29], as negating the requirement to chlorinate the raw material input, has a significant impact on the cost base, signaling a paradigm shift in the production of low cost titanium powder.

\section{Metalysis Titanium Powder Production}

Currently powder manufactured by Metalysis exhibits an angular morphology, analogous to that observed when adopting the hydride - de-hydride method [10], as shown in both (Figure 3) and (Figure 4) overleaf. Additionally it has been established that it is possible to control both the average particle diameter and size distribution of the product, based upon appropriate selection of the oxide [27], as depicted in (Figure 5).

Metalysis powder can also be spheroidized (Figure 6), directly converting the titanium generated in the cell, where recoveries near $100 \%$ are achieved. There is a slight shift in the particle volume and its accompanying distribution, however this can be compensated for by adjustment to the feed. The capacity to target a defined size range bespoke to certain powder metallurgy techniques, provides a distinct advantage over incumbent technologies such as gas atomization (GA/VIGA), or the rotating electrode process (REP). Both have the propensity to create an 
appreciable amount of oversize compared to FFC®, as illustrated in (Figure 5), reiterating the benefits of this approach.
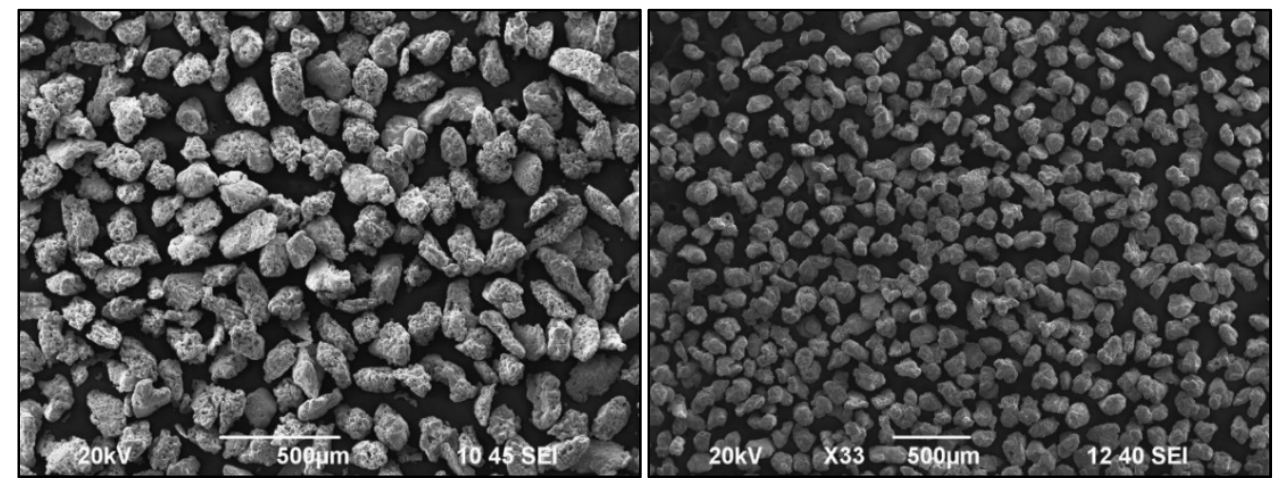

Figure 3 SEM Micrographs of Metalysis Conventional ASTM Grades of Titanium Powder Directly from the Process-Commercially Pure (left) and Ti-6Al-4V (right).
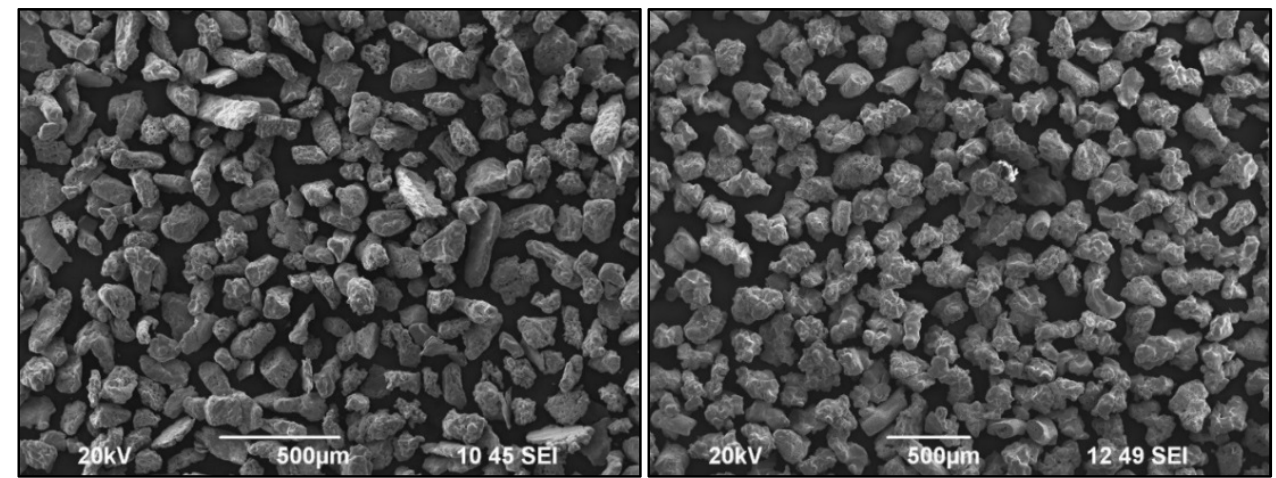

Figure 4 SEM Micrographs of Metalysis Rutile Grades of Titanium Powder Directly from the Process - Natural (left) and Synthetic (right).
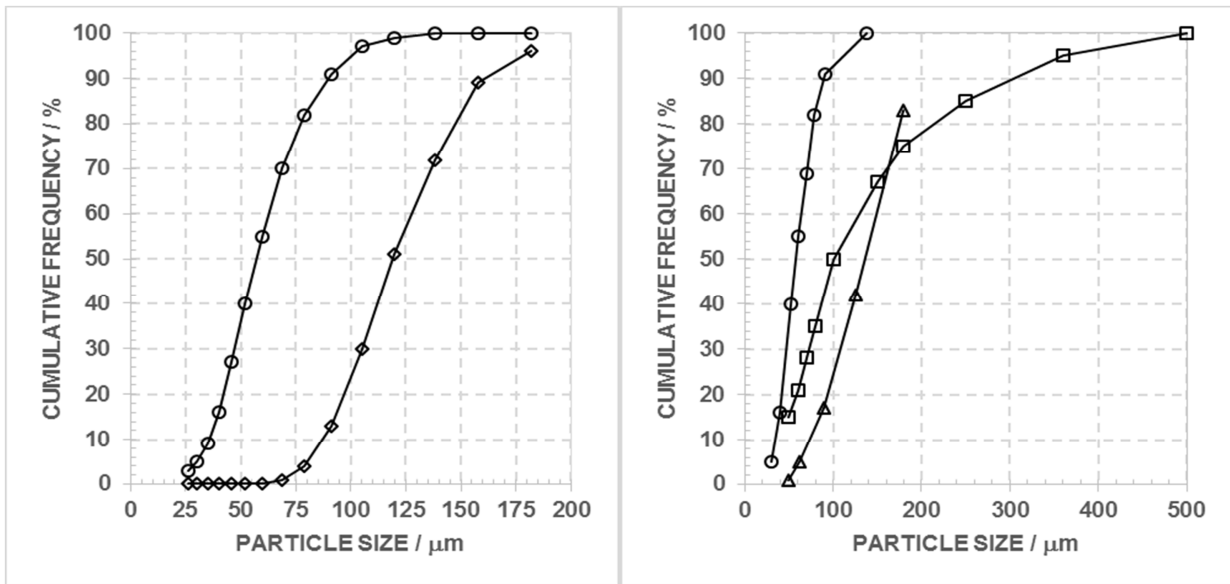

Figure 5 Plots Demonstrating the Ability to Tailor Particle Size Distribution (O) based Upon Selection of the Feed $(\diamond)$ and Comparison versus GA/VIGA $(\square)$ and REP $(\Delta)$ Prior to Classification [8]. 


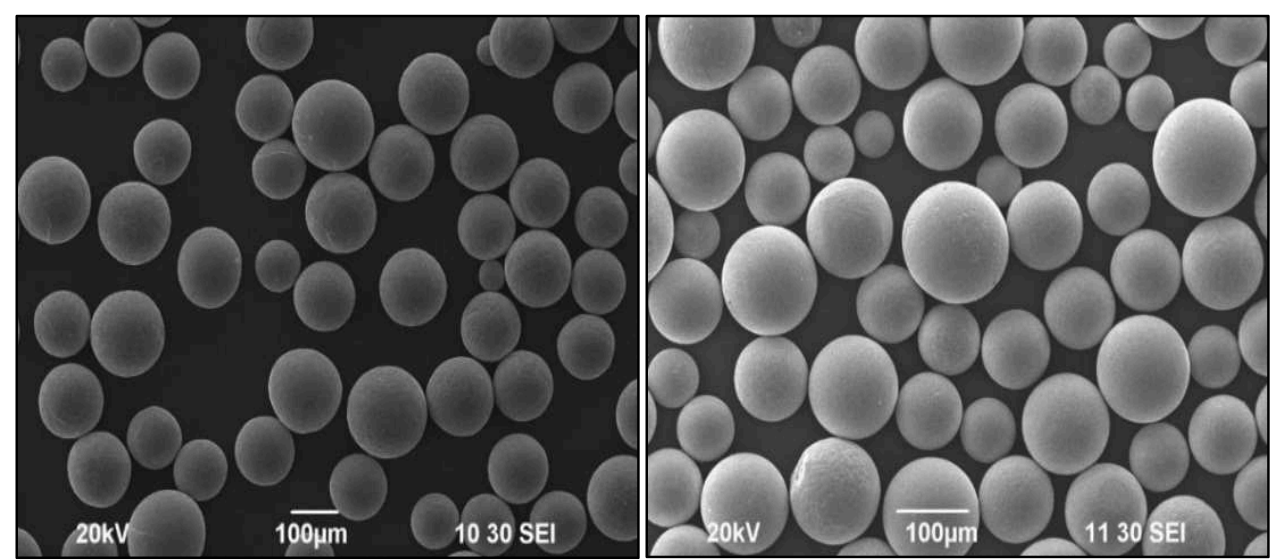

Figure 6 SEM Micrographs of Metalysis Spherical Titanium Powders Produced from both High Purity Pigment Grade Titania (left) and Natural Rutile (Right).

Chemical and physical properties of both the high purity pigment (commercially pure) and natural rutile grades of spherical titanium powders are given in (Table 4) below.

Table 4 Chemical and Physical Properties of Metalysis Spherical Grade Titanium Powders.

\begin{tabular}{|l|c||c|c|}
\hline PROPERTY & UNITS & $\begin{array}{c}\text { SPHERICAL } \\
\text { PIGMENT }\end{array}$ & $\begin{array}{c}\text { SPHERICAL } \\
\text { NAT. RUTILE }\end{array}$ \\
\hline \hline Oxygen & $\mathrm{wt} \%$ & $0.2-0.4$ & $0.15-0.4$ \\
\hline Apparent Density & $\mathrm{g} / \mathrm{cm}^{3}$ & 2.71 & 2.76 \\
\hline Tap Density & $\mathrm{g} / \mathrm{cm}^{3}$ & 2.92 & 2.95 \\
\hline Hall Flow & $\mathrm{s} / 50 \mathrm{~g}$ & 23 & 22 \\
\hline PSD d10 & $\mu \mathrm{m}$ & 88 & 77 \\
\hline PSD d50 & $\mu \mathrm{m}$ & 117 & 105 \\
\hline PSD d90 & $\mu \mathrm{m}$ & 166 & 151 \\
\hline
\end{tabular}

\section{Additive Manufacturing Case Study}

Selective Laser Melting (SLM) trials of natural rutile derived powder were performed on a Renishaw SLM 125 machine, equipped with a ytterbium fiber laser of wavelength $1000 \mathrm{~nm}$, capable of a maximum power output of $200 \mathrm{~W}$. An initial design of experiments was devised based on a range of melt themes (i.e. speed of movement across the bed \& laser power output), to generate a $3 \times 3$ grid of $1 \times 1 \times 1 \mathrm{~cm}$ cubes and ascertain the preferred deposition parameters. Consequently a number of blocks were built in a horizontal orientation from the base plate, i.e. along the X-Y plane, from which specimens were machined to conduct monotonic tensile testing, as per method BS EN 2002-2:2005. Preliminary results indicate an ultimate tensile strength (UTS) of 802MPa, being of a similar magnitude to the $848 \mathrm{MPa}$ measured during hot isostatic pressing (HIP) studies [27], and approaching the $895 \mathrm{MPa}$ of ASTM grade 5 (Ti-6Al-4V).

Following the success of this preliminary proof of concept, a number of demonstration parts were fabricated, applicable to a range of industrial sectors. Examples include an automotive turbocharger component [27], and a guide vane, forming a portion of an aerospace gas turbine, being portrayed in (Figure 7). Metallographic specimens were prepared by slicing, mounting and polishing segments of the build, where an SEM image illustrating a combination of cross-sectional microstructure and final density, is also shown. 


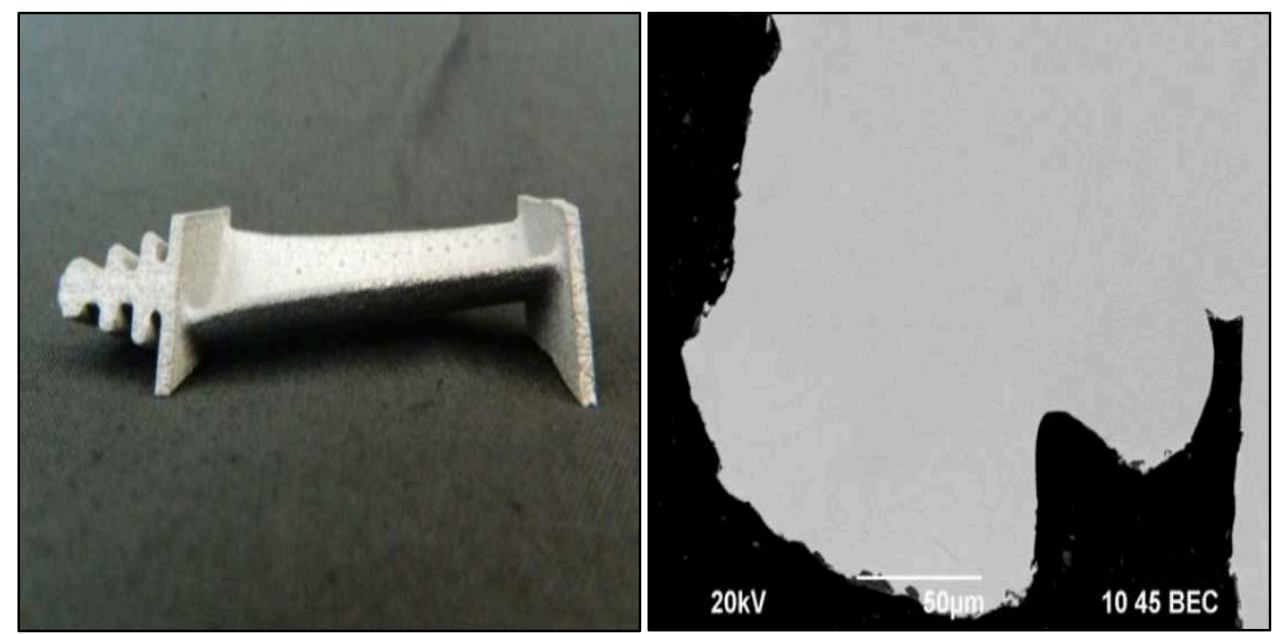

Figure 7 Additively Manufactured Aerospace Turbine Guide Vane Part (left) Fabricated by Selective Laser Melting and Associated SEM Cross Sectional Microstructure Analysis (right).

\section{Summary}

The outlook for the titanium powder industry remains optimistic, with demand continuing to increase, fueled by the growth of additive manufacturing, providing the momentum for the continued investment in developing new, or improving existing processes. Several of these, at various stages of maturity, have been cited as part of this review, where each has the opportunity to carve its own niche, based upon ultimate form, compositional and purity requirements. By demonstrating that it is possible to generate powder directly from the FFC $®$ process, of differing morphologies and alloy chemistries, Metalysis is well positioned to disrupt, and establish itself within the market. In a recent development, both synthetic and naturally occurring rutile have been revealed as suitable feedstocks, as a cheaper alternative to pigment grade titania. Furthermore the ability to produce products tailored towards targeted powder metallurgy techniques, by controlling the average particle diameter and its associated size distribution, allows Metalysis to simultaneously traverse two current global revolutions being (i) shaping the economics and complexity of titanium production by collapsing steps in conventional metallurgy, and (ii) delivering low cost consumables to $3 \mathrm{D}$ printing.

\section{References}

[1] E. H. Kraft, Summary of emerging titanium cost reduction technologies, US Department of Energy and Oak Ridge National Laboratory Subcontract 4000023694, 2004.

[2] F. H. Froes, Titanium Powder Metallurgy: A Review - Part 1, Adv. Mater. Processes 170 (September 2012) $16-21$.

[3] G. M. Delphine Cantin, N. A. Stone, D. Alexander, M. A. Gibson, D. Ritchie, R. Wilson, M. Yousuff, R. Rajakumar and K. Rogers, Production of Ti-6Al-4V by direct rolling of blended elemental powder, Mater. Sci. Forum 654 - 655 (2010) 807 - 810.

[4] B. Thomas, F. Derguti and M. Jackson, Continuous extrusion of titanium particulates, Proceedings of the $13^{\text {th }}$ World Conference on Titanium, San Diego, USA, $16^{\text {th }}-20^{\text {th }}$ August 2015.

[5] D. Whittaker and F. H. Froes, Future prospects for titanium powder metallurgy markets, in: M. Qian and F. H. Froes (Eds.), Titanium Powder Metallurgy - Science, Technology and Applications, Butterworth-Heinemann, Waltham, Massachusetts, 2015, pp. $579-600$.

[6] Information on http://materialstoday.com/additive-manufacturing/news/titanium-sales-in-amcould-exceed-us300-million/. 
[7] F. H. Froes, Titanium Powder Metallurgy: A Review - Part 2, Adv. Mater. Processes 170 (October 2012) $26-29$.

[8] Y. H. Moll and C. F. Yolton, Production of titanium powder, in: P. W. Lee, Y. Trudel, R. Iacocca, R. M. German, B. L. Ferguson, W. B. Eisen, K. Moyer, D. Madan and H. Sanderow (Eds.), ASM Handbook, Volume 7: Powder Metal Technologies and Applications, ASM International, Materials Park, Ohio, 1998, pp. 160 - 166.

[9] O. Neikov, Non-ferrous powder production: Manufacturing methods and properties of copper, aluminium, titanium and nickel powders, Powder Metallurgy Review 3 (Summer 2014) 65 87.

[10]C. McCracken, Production of fine titanium powders via the hydride - dehydride (HDH) process, Powder Injection Moulding International 2 (June 2008) 1 - 3.

[11]J. D. Paramore, Z. Z. Fang, P. Sun, M. Koopman, K. S. Ravi Chandran and M. Dunstan, A powder metallurgy method for manufacturing Ti-6Al-4V with wrought-like microstructures and mechanical properties via hydrogen sintering and phase transformation (HSPT), Scripta Mater. 107 (2015) 103 - 106.

[12]D. S. van Vuuren, S. Oosthuizen and M. D. Heydenrych, Titanium production via metallothermic reduction of $\mathrm{TiCl}_{4}$ in molten salt: problems and products, J. S. Afr. Inst. Min. Metall. 111 (2011) $141-148$.

[13]Z. Z. Fang, S. Middlemas, J. Guo and P. Fan, A new, energy-efficient chemical pathway for extracting Ti metal from Ti minerals, J. Am. Chem. Soc. 135 (2013) 18248 - 18251.

[14]H. Zheng, H. Ito and T. H. Okabe, Production of titanium powder by the calciothermic reduction of titanium concentrates or ore using the preform reduction process, Mater. Trans., JIM 48 (2007) 2244 - 2251.

[15]D. S. van Vuuren, Direct Titanium Powder Production by Metallothermic Processes, in: M. Qian and F. H. Froes (Eds.), Titanium Powder Metallurgy - Science, Technology and Applications, Butterworth-Heinemann, Waltham, Massachusetts, 2015, pp. 69 - 93.

[16]D. S. van Vuuren, A critical evaluation of processes to produce primary titanium, J. S. Afr. Inst. Min. Metall. 109 (2009) $455-461$.

[17] G. Z. Chen, D. J. Fray and T. W. Farthing, Direct electrochemical reduction of titanium dioxide to titanium in molten calcium chloride, Nature 407 (2002) $361-364$.

[18]R. O. Suzuki, K. Teranuma and K. Ono, Calciothermic reduction of titanium dioxide and insitu electrolysis in molten $\mathrm{CaCl}_{2}$, Metall. Mater. Trans B 34B (2003) $287-295$.

[19] A. M. Martinez, K. S. Osen, E. Skybakmoen, O. S. Klos, G. M. Haarberg and K. Dring, A new method for low-cost titanium production. Key. Eng. Mater. 436 (2010) $41-53$.

[20]J. C. Withers, Production of Titanium Powder by an Electrolytic Method and Compaction of the Powder, in: M. Qian and F. H. Froes (Eds.), Titanium Powder Metallurgy - Science, Technology and Applications, Butterworth-Heinemann, Waltham, Massachusetts, 2015, pp. 33 -49 .

[21]P. C. Pistorius and F. Fatollahi-Fard, Production of titanium oxycarbide from titania-rich mineral sands, TMS Annual Meeting (2015) 297 - 304.

[22]S. Jiao and H. Zhu, Novel metallurgical process for titanium production, J. Mater. Res. 21 (2006) $2172-2175$.

[23]J. M. Capus, Metal Powders: A Global Survey of Production, Applications and Markets 20012010, fourth ed., Elsevier, New York, 2005. 
[24]B. Beauchamp, Raymor AP\&C: Leading the way with plasma atomised Ti spherical powders for MIM, Powder Injection Moulding International 5 (December 2011) 55 - 57.

[25]A. J. Fenn, G. Cooley, D. Fray and L. Smith, Exploiting the FFC Cambridge process, Adv. Mater. Processes, 162 (2004) $51-53$.

[26]R. Bhagat, M. Jackson, D. Inman and R. Dashwood, Production of Ti-W alloys from mixed oxide precursors via the FFC Cambridge process, J. Electrochem. Soc. 156 (2009) E1 - E7.

[27]I. Mellor, L. Grainger, K. Rao, J. Deane, M. Conti, G. Doughty and D. Vaughan, Titanium Powder Production via the Metalysis Process, in: M. Qian and F. H. Froes (Eds.), Titanium Powder Metallurgy - Science, Technology and Applications, Butterworth-Heinemann, Waltham, Massachusetts, 2015, pp. $51-67$.

[28]L. L. Benson, I. Mellor and M. Jackson, Direct reduction of synthetic rutile using the FFC process to produce low cost novel titanium alloys, J. Mater. Sci, 51 (2016) 4250 - 4261.

[29]R. Hill, Titanium: $21^{\text {st }}$ century metal, PROCESS - CSIRO research in mineral processing and metal production February (2002) $1-2$. 